\title{
Nutrient Composition and Selected Biochemical Effects of Cnidoscolus aconitifolius Leaf Extracts in Male Albino Rats
}

\author{
Chukwu EC ${ }^{1 *}$, Osuocha $\mathrm{KU}^{2}$ and Uhegbu $\mathrm{FO}^{3}$ \\ ${ }^{1}$ Department of Biochemistry, Federal University Lafia, Nasarwa State, Nigeria \\ ${ }^{2}$ Department of Biochemistry, Gregory University Uturu, Abia State, Nigeria \\ ${ }^{3}$ Department of Biochemistry, Abia state University Uturu, Abia State, Nigeria
}

*Corresponding author: Chukwu EC, Department of Biochemistry, Federal University Lafia, Nasarwa State, Nigeria, Tel: 2348130749040; E-mail: callychuksu@gmail.com

Received date: January 10, 2018; Accepted date: January 16, 2018; Published date: January 22, 2018

Copyright: @ 2018 Chukwu EC, et al. This is an open-access article distributed under the terms of the Creative Commons Attribution License, which permits unrestricted use, distribution, and reproduction in any medium, provided the original author and source are credited.

\begin{abstract}
The present study evaluated nutritional constituents of Cnidoscolus aconitifolius leaf and examined the effect of aqueous and ethanol extracts on selected biochemical parameters using male albino rats. Forty five male albino rats weighing $(115-121 \mathrm{~g})$ were used for the study. The rats were randomly divided into nine groups of five rats each. Group I served as the control while the other groups were administered $200,400,600$ and $800 \mathrm{mg} / \mathrm{kg}$ body weight of aqueous and ethanol leaf extracts. Mineral, proximate and vitamin analysis showed that the plant leaf contains appreciable amount of vitamin and minerals analysed. Results showed significant difference $(P<0.05)$ between the control and Cnidoscolus aconitifolius leaf extracts administered rats with respect to body weight changes, liver function indices and hematological parameters (White Blood Cells) in dose dependent ratio. From this study, aqueous leaf extract of Cnidoscolus aconitifolius at doses of 400,600 and $800 \mathrm{mg} / \mathrm{kg}$ body weight showed evidence of cumulative toxicity. It is therefore suggestive to say that in order to ensure holistic safe utilization, bioactive constituents of Cnidoscolus aconitifolius leaf may be better extracted using ethanol as it has not shown any evidence of hepatotoxicity.
\end{abstract}

Keywords: Nutrient composition; Cnidoscolus aconitifolius; Biochemical indices

\section{Introduction}

Medicinal plants are the richest bio-resource of drugs for traditional system of medicine especially in most developing countries. Dhanalakshmi and Manavalan [1], opined that plants owing to its medicinal efficacy have continued to play a dominant role in the maintenance of human health. Plant derived medicinal compounds have been part of the evolution of human healthcare for thousands of years [2]. According to Ebeye, et al. [3], many people have for centuries developed various herbal medicines using locally available plants as remedy to their health problems. Oluwatosin, et al. [4] also reported that herbal medicines derived from plant extracts are increasingly being utilized to treat a wide variety of diseases and these plants serves as good sources of bioactive compounds that may boost the endogenous antioxidant defense system. Cnidoscolus aconitifolius belong to the family of Euphorbiaceae. It is an evergreen, drought deciduous shrubs up to $6 \mathrm{~m}$ in height with alternate palmate lobed leaves, milky sap and small flowers on dichotomously branched cymes [5]. Fagbohun, et al. [6] noted that leaf extract of Cnidoscolus aconitifolius has been implicated in management of diabetes. In Southwest and eastern Nigeria, the leaves and young shoots are often squeezed with water and drank alone or with milk and tomato paste added. The local folks believe that it has a blood boosting effect and is commonly taken by pregnant women and young children who are anemic [7]. Aqueous leaf extract has also been recommended as a female contraceptive [8]. The World Health Organization (WHO, 2013) has emphasized the need to ascertain the actual bioactive constituents and quality of medicinal plants products. This is necessary especially for plants like Cnidoscolus aconitifolius that has been used for treatment of various diseases. In view of all the reputed medicinal efficacy of this plant leaf there is need to determine the nutrient constituents of Cnidoscolus aconitifolius leaf and evaluate the biochemical changes that may be associated with consumption of aqueous and ethanol leaf extracts of this plant in order to ensure holistic utilization of this plant leaves for treatment of diseases.

\section{Method of analysis}

\section{Collection of plant material}

Cnidoscolus aconitifolius leaves were harvested from Acha in Isuikwuato L.G.A Abia State Nigeria. The leaves were separated from stem, washed with clean water and dried at room temperature. The dried plant leaves were ground into powder form using blender which was transferred into an air tight container stored at room temperature.

\section{Determination of proximate composition}

Moisture, fibre and ash content were determined by the method described by James [9] while protein content was determined by the Kjeldahl method of Chang [10]. Carbohydrate content was ascertained using the method of Muller and Tobin, (11) while lipid content was determined by Soxhlet Extraction Gravimeteric method of Kirk and Sawyer [12].

\section{Vitamin determination}

Retinol content of plant sample was determined by the method of AOAC, [13]. Ascorbic acid content was done using Barakat, [14] 
method. Vitamin B6, B12, B3, B1 were also analysed using the method of AOAC (13) while mineral content were analysed with the method of AOAC [13].

\section{Mineral determination}

Mineral content of plant sample was determined by Atomic Absorption Spectrophotometer as described by James, [9]. Following the ashing of sample, the resulting ash was dissolved in $10 \mathrm{mls}$ of Hydrochloric Acid (HCL).It was filtered with Whatman \#42 filter paper. The extract was used for the analysis using Atomic Absorption Spectrophotometer (AAS).

\section{Preparation of aqueous leaf extract}

Exactly $200 \mathrm{~g}$ of the powdered plant were measured into a conical flask and $500 \mathrm{ml}$ of water were added and left at room temperature for 48 hours. The extracts were filtered. The filtrate was evaporated to dryness on a water bath to give a crude extract. The extraction efficiency was quantified by determining the weight of the extract. The dried extract was stored in desiccators until required for use. The extract was dissolved in appropriate volume of distilled water to the desired concentration [15].

\section{Preparation of ethanol leaf extract}

Exactly $200 \mathrm{~g}$ of the powdered plant were measured into a conical flask and $500 \mathrm{ml}$ of $70 \%$ ethanol were added and left at room temperature for 48 hours. The extract was filtered. The filtrate was evaporated to dryness on a water bath (500C) to give the crude extract, which the mass was determined.

\section{Experimental design}

Forty five male albino rats aged 9 weeks weighing $115 \mathrm{~g}-121 \mathrm{~g}$ were used for this study. The animals were randomly divided into nine (9) groups of five rats each for biochemical assessment of the effect of aqueous and ethanol extracts of Cnidoscolus aconitifolius leaves. Group I served as control, Group II received $200 \mathrm{mg}$ of aqueous extract, Group III received $400 \mathrm{mg}$ of aqueous extract per $\mathrm{kg}$ body weight, Group IV received 600mg of aqueous extract, and Group V received $800 \mathrm{mg}$ of aqueous extract. Group VI received $200 \mathrm{mg}$ of ethanol extract while Group VII received $400 \mathrm{mg}$ of ethanol extract per $\mathrm{kg}$ body weight. Group VIII received 600 while Group IX received $800 \mathrm{mg}$ of ethanol extract. Each group of animals were housed in a standard rat cage and allowed to acclimatize to laboratory condition for one week prior to commencement of feeding experiments. All rats were allowed free access to water and feed ad libitum. The method of administration of the extracts was by oral guavage which lasted for twenty eight days.

\section{Blood Collection}

Twenty eight days after feeding the rats with the leaf extracts of Cnidoscolus aconitifolius, they were fasted overnight, anaesthetized with chloroform and sacrificed. Blood was collected by cardiac puncture using syringe and needle and blood samples from each animal collected into dry test tubes. The blood sample was divided into two. The first part was dispensed into heparinized tubes for hematological analysis. The second part of the blood sample was allowed to stand for about 15 minutes to clot and further spun in a centrifuge. Serum was separated from the clot with Pasteur pipette into sterile sample test tubes for the measurement of liver enzymes and other parameters.

\section{Hematological determination}

The method of cynomethamoglobin as described by Ramnik was used for determination of hemoglobin level. The method of formol citrate solution counting was used for counting the red blood cells [16] Turk's solution method was used in white blood cell determination [17].

\section{Determination of liver function status}

Serum Alanine Aminotransferase (ALT) and Serum Aspartate Aminotransferase (AST activities were determined using the colorimetric method described by Reitman and Frankel [18] while serum alkaline phosphatase (ALP) was determined as described by Bassey, et al. [19] using commercial diagnostic kit (Randox, United Kingdom).

Serum total protein was determined by the method described by Henry, et al. [20] while Albumin concentration of the serum was determined using commercial diagnostic kit (Fortres, United Kingdom). The method used was Bromocresol Green (BCG) as described by Dournan, et al. [21].

\section{Statistical analysis}

The statistical analysis of result was done using students package for social sciences (SPSS) version 20 computer software and data collected were analyzed using Analysis of Variance (ANOVA).Means were separated using Least Significant Difference.

\section{Results}

Values are mean of mean of triplicate determination (Table 1).

\begin{tabular}{|l|l|}
\hline Sodium & 7.32 \\
\hline Potassium & 58.45 \\
\hline Calcium & 44.82 \\
\hline Magnesium & 23.46 \\
\hline Zinc & 1.48 \\
\hline Iron & 0.04 \\
\hline
\end{tabular}

Table 1: Mineral composition of Cnidoscolus aconitifolius leaf (mg/ 100g).

Mineral analysis of Cnidoscolus aconitifolius shows $7.32 \mathrm{mg} / 100 \mathrm{~g}$ of sodium, $58.45 \mathrm{mg} / 100 \mathrm{~g}$ potassium, $44.82 \mathrm{mg} / 100 \mathrm{~g}$ calcium, $23.46 \mathrm{mg} /$ $100 \mathrm{~g}$ magnesium, $1.48 \mathrm{mg} / 100 \mathrm{~g}$ zinc and $0.04 \mathrm{mg} / 100 \mathrm{~g}$ iron.

Values are mean of mean of triplicate determination (Table 2)

\begin{tabular}{|l|l|}
\hline Ash & 14.78 \\
\hline Moisture & 5.53 \\
\hline Protein & 19.41 \\
\hline Lipids & 12.52 \\
\hline
\end{tabular}


Citation: Chukwu EC, Osuocha KU, Uhegbu FO (2018) Nutrient Composition and Selected Biochemical Effects of Cnidoscolus aconitifolius Leaf Extracts in Male Albino Rats. J Forensic Res 9: 409. doi:10.4172/2157-7145.1000409

Page 3 of 7

\begin{tabular}{|l|l|}
\hline Fibre & 7.71 \\
\hline Carbohydrate & 40.05 \\
\hline
\end{tabular}

Table 2: Percentage (\%) proximate composition of Cnidoscolus aconitifolius leaf.

Proximate analysis of Cnidoscolus aconitifolius leaves shows that the plant contains $14.78 \%$ ash, $5.53 \%$ moisture, $19.41 \%$ protein, $12.52 \%$ lipids, $7.71 \%$ fibre and $40.05 \%$ carbohydrate.

Values are mean of mean of triplicate determination (Table 3).

\begin{tabular}{|l|l|}
\hline Vitamin A & 3.41 \\
\hline Vitamin B3 & 2.32 \\
\hline
\end{tabular}

\begin{tabular}{|l|l|}
\hline Vitamin B5 & 1.11 \\
\hline Vitamin B6 & 30.34 \\
\hline Vitamin B12 & 11.86 \\
\hline Vitamin C & 19.19 \\
\hline
\end{tabular}

Table 3: Vitamin composition of Cnidoscolus aconitifolius leaf (mg/ $100 \mathrm{~g})$.

Vitamin analysis of Cnidoscolus aconitifolius leaf shows that the plant leaf contains $3.41 \mathrm{mg} / 100 \mathrm{~g}$ of Vitamin A, $2.32 \mathrm{mg} / 100 \mathrm{~g}$ of Vitamin B3, $1.11 \mathrm{mg} / 100 \mathrm{~g}$ of Vitamin B5, 30.34mg/100g of Vitamin B6, $11.86 \mathrm{mg} / 100 \mathrm{~g}$ of Vitamin B12 and $19.19 \mathrm{mg} / 100 \mathrm{~g}$ of vitamin C (Table $4)$.

\begin{tabular}{|l|l|l|l|}
\hline Groups & Initial Body weight(g) & Final Body Weight(g) & Change in weight(g) \\
\hline Group I & $120.78 \pm 1.48$ & $135.95 \pm 1.42$ & 12.56 \\
\hline Group II & $121.13 \pm 1.23$ & $134.78 \pm 0.69$ & 11.26 \\
\hline Group III & $115.45 \pm 1.04$ & $125.70 \pm 0.69$ & 8.87 \\
\hline Group IV & $118.38 \pm 2.13$ & $125.15 \pm 1.76$ & 5.71 \\
\hline Group V & $120.13 \pm 0.69$ & $125.50 \pm 1.31$ & 4.09 \\
\hline Group VI & $119.95 \pm 0.95$ & $132.50 \pm 0.75$ & 10.46 \\
\hline Group VII & $118.10 \pm 1.04$ & $133.40 \pm 0.78$ & 12.95 \\
\hline Group VIII & $121.95 \pm 1.63$ & $141.50 \pm 2.34$ & 16.03 \\
\hline Group IX & $117.18 \pm 0.48$ & $141.93 \pm 2.33$ & 21.12 \\
\hline LSD & 1.8486 & 2.1542 & \\
\hline
\end{tabular}

Table 4: Body weight effect of Cnidoscolus aconitifolius leaf extracts on male albino rats $(\mathrm{g}) ; \mathrm{n}=5 ;{ }^{*}$ indicates significant difference from the control $(\mathrm{P}<0.05)$.

Total protein results ranged from $5.72 \mathrm{mg} / \mathrm{dl}$ in group $\mathrm{V}$ to $6.85 \mathrm{mg} / \mathrm{dl}$ in IX. Result shows significant decrease $(\mathrm{P}>0.05)$ in the total protein level of rats fed with aqueous leaf extract (II, III, IV and V) relative to control $(6.50 \mathrm{mg} / \mathrm{dl})$ and the groups treated with ethanol leaf extract (VI, VII, VIII and IX) which recorded $6.52 \mathrm{mg} / \mathrm{dl}, 6.57 \mathrm{mg} / \mathrm{dl}$, $6.61 \mathrm{mg} / \mathrm{dl}$ and $6.85 \mathrm{mg} / \mathrm{dl}$. Results of albumin level shows significant decrease in the groups treated with aqueous leaf extract (II-V) which recorded $7.91 \mathrm{mg} / \mathrm{dl}, 7.36 \mathrm{mg} / \mathrm{dl}, 7.20 \mathrm{mg} / \mathrm{dl}$ and $6.92 \mathrm{mg} / \mathrm{dl}$ compared to control $(8.20 \mathrm{mg} / \mathrm{dl})$ and the groups treated with ethanol leaf extract which recorded $8.22 \mathrm{mg} / \mathrm{dl}$ group VI, $8.27 \mathrm{mg} / \mathrm{dl}$ group VII, $8.25 \mathrm{mg} / \mathrm{dl}$ group VIII and $8.31 \mathrm{mg} / \mathrm{dl}$ group IX. Serum total bilirubin level shows non-significant increase in the groups treated with aqueous leaf extract. Results shows total bilirubin levels as $0.21 \mathrm{mg} / \mathrm{dl}, 0.29 \mathrm{mg} / \mathrm{dl}$, $0.30 \mathrm{mg} / \mathrm{dl}$ and $0.33 \mathrm{mg} / \mathrm{dl}$ for groups II, III, IV and V while $0.22 \mathrm{mg} / \mathrm{dl}$, $0.24 \mathrm{mg} / \mathrm{dl}, 0.22 \mathrm{mg} / \mathrm{dl}$ and $0.25 \mathrm{mg} / \mathrm{dl}$ were recorded for groups VI, VII, VIII and IX treated with ethanol leaf extract of Cnidoscolus aconitifolius (Table 5).

\begin{tabular}{|l|l|l|l|l|}
\hline Groups & Hemoglobin(g/dl) & PCV (\%) & RBC(1012/I) & WBC(109/I) \\
\hline Group I & $12.03 \pm 0.05$ & $35.40 \pm 0.29$ & $4.70 \pm 0.08$ & $5.15 \pm 0.13$ \\
\hline Group II & $12.33 \pm 0.10$ & $35.90 \pm 0.00$ & $4.90 \pm 0.00$ & $5.73 \pm 0.21$ \\
\hline Group III & $12.53 \pm 0.05$ & $36.18 \pm 0.01$ & $4.93 \pm 0.63$ & $7.65 \pm 0.24^{*}$ \\
\hline Group IV & $12.58 \pm 0.05$ & $36.03 \pm 0.64$ & $5.05 \pm 0.44$ & $7.70 \pm 0.24^{*}$ \\
\hline Group V & $12.80 \pm 0.00$ & $36.03 \pm 0.05$ & $4.75 \pm 0.13$ & $7.98 \pm 0.10^{*}$ \\
\hline Group VI & $12.83 \pm 0.21$ & $36.68 \pm 0.39$ & $5.05 \pm 0.06$ & $5.63 \pm 0.21$ \\
\hline
\end{tabular}


Citation: Chukwu EC, Osuocha KU, Uhegbu FO (2018) Nutrient Composition and Selected Biochemical Effects of Cnidoscolus aconitifolius Leaf Extracts in Male Albino Rats. J Forensic Res 9: 409. doi:10.4172/2157-7145.1000409

Page 4 of 7

\begin{tabular}{|l|l|l|l|l|}
\hline Group VII & $12.40 \pm 0.14$ & $35.92 \pm 0.04$ & $4.83 \pm 0.10$ & $5.48 \pm 0.32$ \\
\hline Group VIII & $12.78 \pm 0.15$ & $36.55 \pm 0.41$ & $5.10 \pm 0.29$ & $5.50 \pm 0.54$ \\
\hline Group IX & $12.98 \pm 0.26$ & $36.83 \pm 0.36$ & $5.03 \pm 0.15$ & $5.50 \pm 0.32$ \\
\hline LSD & 0.2004 & 0.4733 & 0.4154 & 0.4123 \\
\hline
\end{tabular}

Table 5: Hematological evaluation of rats fed with Cnidoscolus aconitifolius leaf extracts. $n=5$, Results represent mean of triplicate determinations \pm standard deviation. ${ }^{*}$ indicates significant difference from control $(\mathrm{P}<0.05)$.

Table 6 below shows the effect of aqueous and ethanol leaf extracts of Cnidoscolus aconitifolius on liver function indices. Results shows that Alanine transaminase (ALT) ranged from $29.40 \mathrm{IU} / \mathrm{L}$ in the control to $37.03 \mathrm{IU} / \mathrm{L}$ in group V. Findings shows that the group treated with aqueous leaf extract (II to $\mathrm{V}$ ) has the highest ALT values of $32.55 \mathrm{IU} / \mathrm{L}, 34.58 \mathrm{IU} / \mathrm{L}$ and $37.03 \mathrm{IU} / \mathrm{L}$ compared to control $(29.40$ $\mathrm{IU} / \mathrm{L})$ and the group treated with ethanol leaf extract of Cnidoscolus aconitifolius (VI, VII, VIII and IX) which had ALT value of 31.05IU/L, $30.15 \mathrm{IU} / \mathrm{L}, 30.15 \mathrm{IU} / \mathrm{L}$ and $30.18 \mathrm{IU} / \mathrm{L}$. Aspartate transaminase (AST) results shows that AST values ranged from 13.03 IU/L in the control to $16.88 \mathrm{IU} / \mathrm{L}$ in group V. Results shows that the group treated with aqueous leaf extract $(\mathrm{II}-\mathrm{V})$ recorded significant increase $(\mathrm{P}<0.05)$ in AST activities compared to control 13.03IU/L and the groups treated with ethanol leaf extract which recorded $13.35 \mathrm{IU} / \mathrm{L}, 13.95 \mathrm{IU} / \mathrm{L}$, 14.11IU/L and 14.18IU/L in groups VI, VII, VII and IX. Alkaline phosphatase results ranged from $89.58 \mathrm{IU} / \mathrm{L}$ in the control to 95.75 IU/L in group V. Results also shows that the group treated with aqueous leaf extract $(\mathrm{II}-\mathrm{V})$ recorded significant increase $(\mathrm{P}<0.05)$ in ALP values compared to control 89. $58 \mathrm{IU} / \mathrm{L}$ and the groups treated with ethanol leaf extract which recorded $89.93 \mathrm{IU} / \mathrm{L}, 90.18 \mathrm{IU} / \mathrm{L}$, 90.40IU/L and 40.90 IU/L in groups VI, VII, VII and IX.

\begin{tabular}{|c|c|c|c|c|c|c|}
\hline Groups & ALT (IU/L) & AST (IU/L) & ALP (IU/L) & $\begin{array}{l}\text { Total protein } \\
(\mathrm{mg} / \mathrm{dl})\end{array}$ & Albumin(mg/dl) & Total Bilirubin(mg/dl) \\
\hline Group I & $29.40 \pm 1.16$ & $13.03 \pm 0.59$ & $89.58 \pm 0.55$ & $6.50 \pm 0.02$ & $8.20 \pm 0.35$ & $0.21 \pm 0.07$ \\
\hline Group II & $29.88 \pm 0.36$ & $13.68 \pm 0.22$ & $89.63 \pm 0.48$ & $6.20 \pm 0.58$ & $7.91 \pm 0.17$ & $0.21 \pm 0.93$ \\
\hline Group III & $32.55 \pm 0.41^{*}$ & $15.63 \pm 0.31^{*}$ & $94.08 \pm 0.51^{*}$ & $5.92 \pm 0.11^{*}$ & $7.36 \pm 0.39^{*}$ & $0.29 \pm 0.02$ \\
\hline Group IV & $34.58 \pm 0.26^{*}$ & $15.80 \pm 0.14^{*}$ & $94.93 \pm 0.13^{*}$ & $5.81 \pm 0.04^{*}$ & $7.20 \pm 0.17^{\star}$ & $0.30 \pm 0.04$ \\
\hline Group V & $37.03 \pm 1.26^{*}$ & $16.88 \pm 0.26^{*}$ & $95.75 \pm 0.53^{*}$ & $5.72 \pm 0.35^{*}$ & $6.92 \pm 0.27^{*}$ & $0.33+0.10$ \\
\hline Group VI & $31.05 \pm 0.57$ & $13.35 \pm 0.13$ & $89.93 \pm 0.67$ & $6.52 \pm 0.20$ & $8.22 \pm 0.16$ & $0.22 \pm 0.62$ \\
\hline Group VII & $30.15 \pm 0.17$ & $13.95 \pm 0.49$ & $90.18 \pm 0.17$ & $6.57 \pm 0.09$ & $8.27 \pm 0.65$ & $0.24 \pm 0.07$ \\
\hline Group VIII & $30.15 \pm 0.13$ & $14.11 \pm 0.31$ & $90.40 \pm 0.98$ & $6.61 \pm 0.15$ & $8.25 \pm 0.05$ & $0.22 \pm 0.05$ \\
\hline Group IX & $30.18 \pm 0.26$ & $14.18 \pm 0.36$ & $90.90 \pm 0.00$ & $6.85 \pm 0.41$ & $8.31 \pm 0.38$ & $0.25 \pm 0.01$ \\
\hline LSD & 0.9341 & 0.5 & 0.7686 & 0.8342 & 0.6357 & 0.4057 \\
\hline
\end{tabular}

Table 6: Liver function assessment of rat fed with Cnidoscolus aconitifolius leaf extracts; $n=5$; Results represent mean of triplicate determinations \pm standard deviation; ${ }^{*}$ indicates significant difference from the control $(\mathrm{P}<0.05)$.

\section{Discussion}

Mineral composition is a measure of the amount of specific inorganic components present within a food [22]. Mineral analysis of Cnidoscolus aconitifolius leaf shows that the plant contains appreciable quantities of the macronutrients necessary for human health maintenance. The mineral compositions are presented in (Table 1). Result shows that Cnidoscolus aconitifolius leaf contains 58.45\% (potassium), 23.46\% (magnesium), $7.32 \%$ (sodium), $44.87 \%$ (calcium), $0.04 \%$ (iron) and $1.48 \%$ (zinc). Potassium has been implicated as an important mineral nutrient in the control of hypertension and in the reduction of risks of stroke [23-24]. Iwuji, et al. [22] noted that Sodium and Potassium deficiencies can cause nausea, anorexia, irritability and muscle weakness. Sodium is associated with Potassium in the body in maintaining acid-base balance and nerve transmissions [25]. The sodium content (7.32\%) recorded from this study is an indication that the plant may not be a good source of sodium. Increased sodium intake has been reported to cause elevated blood pressure [26].The high calcium content (44.87\%) in Cnidoscolus aconitifolius leaf shows that the plant may serve as a rich source of minerals involved in bone formation. Calcium is needed in the development of bone and teeth and it regulate heart rhythm, helps in normal blood clotting, maintain proper nerve and muscle functions and lower blood pressure [6,27]. This may further strengthen the local usage of this plant leaf extracts in treatment of hypertension. Zinc is involved in normal function of immune system and is a component of many enzymes in the body [28]. Otitoju, et al. [29] also demonstrated that zinc stabilizes the molecular structure of cellular components and membranes and contributes in this way to the maintenance of cell and organ integrity. Zinc content obtained from 
the present study shows that it contains $1.48 \%$ of zinc. This however is contrary to the report of Fagbolun, et al. [6] who reported $0.02 \%$ of zinc in Cnidoscolus aconitifolius leaf. This difference could be attributed to variation in seasons and environmental factors or method of analysis. This however may suggest that Cnidoscolus aconitifolius leaf may not be a very good source of zinc.

Magnesium is an important cofactor for the conversion of blood glucose into energy [30]. Findings showed that the plant leaf contains $23.46 \%$ magnesium. Magnesium is a component of chlorophyll which may have contributed to the sole greenish colour of the plant and it is also an important mineral element that plays pivotal role in control of ischemic heart disease such as cardiac excitability, neuromuscular transmission, vasomotor tone, blood pressure and it is involved in calcium metabolism in bones [31], while iron content was found to be $0.04 \%$ and iron has been reported as an essential element for hemoglobin formation, normal functioning of central nervous system and oxidation of carbohydrate, protein and fats [30,32]. Based on the mineral result obtained from this study, Cnidoscolus aconitifolius leaf may be a good dietary source of minerals.

Proximate composition of Cnidoscolus aconitifolius leaf are presented in (Table 2) Findings from this study shows that the plant is a good source of nutrients such as protein, lipids, fibre and carbohydrate. The fibre content recorded from this work shows that the plant may be a moderate source of dietary fibre (7.71\%). Dietary fibre plays an important role in decreasing the risks of many disorders such as constipation, diabetes, cardiovascular diseases and obesity [33]. Fibre intake can stimulate weakening hunger, peristaltic movement and lower the serum cholesterol level [26,34]. Iwuji and Nwafor [35] reported that high fibre content in food can cause intestinal irritation and lower nutrient bioavailability. Lipid content recorded from this work shows that the plant contains $12.52 \%$ lipids. Lipid has been reported to increase food palatability by absorbing and retaining flavors [6]. Protein content showed that Cnidoscolu aconitifolius leaf contain appreciable amount of proteins (19.41\%). This shows that the plant have potential health benefit as proteins are essential for the synthesis of body tissues and regulatory substance such as enzyme and hormones. According to Emebu and Anyika [35] carbohydrates are pivotal nutrients required for adequate diet. The carbohydrate composition of Cnidoscolus aconitifolius leaf obtained from this study shows that the plant leaf contains $40.05 \%$. This shows that the plant meets the Recommended Dietary Allowance (RDA) values for children (40\%), adults (40\%), pregnant women $(30 \%)$ and lactating mothers (25\%).These Recommended Dietary Allowance (RDA) have also been reported by Fagbohun, et al. [6] High carbohydrate content of Cnidoscolus aconitifolius leaf have also been reported by Iwuji, et al. [22]. This findings shows that Cnidoscolus aconitifolius leaves contains appreciable amount of nutritional constituents.

Vitamin composition of Cnidoscolus aconitifolius leaves are presented in (Table 3). Results showed that the plant contain appreciable amount of the various vitamins analysed. Results shows $3.41 \mathrm{mg} / 100 \mathrm{~g}$ of vitamin A, $2.32 \mathrm{mg} / 100 \mathrm{~g}$ of vitamin B3, $1.11 \mathrm{mg} / 100 \mathrm{~g}$ of vitamin $\mathrm{B} 5,30.34 \mathrm{mg} / 100 \mathrm{~g}$ of vitamin $\mathrm{B} 6,11.86 \mathrm{mg} / 100 \mathrm{~g}$ of vitamin $\mathrm{B} 12$ and $19.19 \mathrm{mg} / 100 \mathrm{~g}$ vitamin C. Vitamin A is important for normal vision, gene expression, growth and immune function by its maintenance of epithelial cell functions [36]. Vitamin C is a potent antioxidant that facilitates the transport and uptake of non-heme iron at the mucosa, reduction of folic acid intermediates and the synthesis of cortisol. Otitoju, et al. [29] opined that green vegetables with high ascorbic acid content may enhance the absorption of non-heme iron.
Its deficiency includes fragility to blood capillaries and scurvy. Vitamin $\mathrm{E}$ is a powerful antioxidant which helps to protect cells from damage by free radicals and it is vital for the formation and normal function of red blood cells and muscles [36]. Adequate supply of dietary antioxidants may prevent or delay diabetes complications including renal and neural dysfunction by providing protection against oxidative stress. B vitamins are essential for growth, development and a variety of other bodily functions. They play a major role in the activities of .

The mean body weight changes of rats fed with aqueous and ethanol extract of Cnidoscolus aconitifolius is presented in (Table 4). There was significant percentage weight reduction in rats treated with 400,600 and $800 \mathrm{mg} / \mathrm{kg}$ body weight of aqueous leaf extract of Cnidoscolus aconitifolius in a dose dependent manner. Chinyere, et al. [37] reported that weight reduction in experimental animal may be due to toxicity of the fed diet, unacceptability of diet by animals, indigestion and presence of non-nutritional factors in the diet. Result shows that rats administered ethanol extract had significant percentage weight gain compared to control $(\mathrm{P}<0.05)$. The significant weight gain observed with the rats administered ethanol leaf extract of Cnidoscolus aconitifolius could be as a result of higher extracting potentials of ethanol which tend to extract the bioactive ingredients more. This however can be deduced from the preliminary phytochemical results [38]. This finding is in accordance with the reports of Kim, et al. and Ebeye, et al. [30] who demonstrated significant increase in body weight of albino rats fed with Cnidoscolus aconitifolius ethanol leaf extract. The significant increase in body weight observed from this study could also be due to the fact that Cnidoscolus aconitifolius leaves contain good nutritional constituents which may increase appetite resulting in increased food intake which ultimately may lead to increase in the body weights observed. This shows that the plant ethanol extract could be effective in improving body weight loss. This report is in consonance with the findings of Mordi [39] and Odokuma [40] who posited increase in body weight of rats fed with Cnidoscolus aconitifolius leaves. This study showed significant increase in the groups fed with ethanol extract compared to those fed with aqueous extracts. This could also be as a result of the solvent of extraction which has been reported to be more active in extraction of bioactive ingredients in plant samples.

Hematological indices give insight into the production potential of cells and help to monitor and evaluate incidence of diseases in animals and could also be used to explain blood relating function of a plant extract $[8,38,41]$.The mechanism of White blood cell and its components are defensive against foreign substances. Results showed that the white blood cell count significantly $(\mathrm{P}<0.05)$ increase in groups treated with 400,600 and $800 \mathrm{mg} / \mathrm{kg}$ body weight of aqueous leaf extract relative to control and those treated with ethanol leaf extract $(\mathrm{P}<0.05)$. Okereke, et al. [28] noted that the combined effects of physiological and chemical factors in the metabolic system of animals could lead to increase in white blood cells. This increase was observed to be in a dose dependent manner and could be an indication of the presence of some toxic substances in the system of the rats which may have triggered an immune response leading to increased production of White Blood Cells. Emelike and Unegbu, [24] had earlier posited the presence of hydrocyanic glycoside a toxic compound that is easily destroyed by heat in aqueous leaf extract of Cnidoscolus aconitifolius. This report is also similar to the findings of Oyagbemi, et al. [5] who demonstrated ameliorative effect of Cnidoscolus aconitifolius ethanolic leaf extract on anemic rats. Cnidoscolus aconitifolius. The results also suggest that Cnidoscolus aconitifolius ethanolic leaf extracts could also be used in management of blood related diseases. 
Liver is an organ involved in many metabolic functions and is prone to xenobiotic induced injuries because of their central role in xenobiotic metabolism. The Liver contains a host of enzymes such as Aspartate transaminase (AST), Alanine transaminase (ALT) and alkaline phosphatase (ALP). These enzymes are present in serum in very low concentration and have no known function in the serum other than provide insight about hepatic state and disorder [37]. It is established that AST can be found in the liver, cardiac muscle, skeletal muscle, kidney, brain, pancreas, lungs, leukocytes and erythrocytes whereas ALT is predominantly present in the liver [42]. Increased levels of AST and ALT in the serum have been reported as an indication of increased permeability and damage and/or necrosis of hepatocytes $[4,42]$. The membrane bound enzymes like ALP are released into bloodstream depending on the pathological phenomenon [4]. The activities of these enzymes are also used to assess the functional status and serve as biochemical markers of liver damage [39]. Majekodunmi, et al. [43] noted that elevated levels of these enzyme in the blood serum has been ascribed to be as a result of damaged structural integrity of the liver and are indicative of cellular leakage and loss of functional integrity. The results from this study (Table 7) showed that there was significant increase $(\mathrm{P}<0.05)$ in the activities of ALP, AST and ALT upon administration of 200, 400 and $800 \mathrm{mg}$ of aqueous leaf extract of Cnidoscolus aconitifolius. This shows that there is evidence of cumulative toxicity as reflected by degenerative changes in the liver of the animals examined. Findings from this study is contrary to the reports of Mordi and Akanji, [39] who reported non- significant changes in liver enzyme activity of rats fed with aqueous leaf extract of Cnidoscolus aconitifolius. Results also showed non-significant increase $(\mathrm{P}>0.05)$ in the activities of ALP, ALT and AST in rats treated with ethanol leaf extract of Cnidoscolus aconitifolius. This also is an indication that Cnidoscolus aconitifolius ethanolic leaf extract did not induce pathological changes in the liver but rather may have hepatoprotective potentials. Similar finding have also been reported by Ekeleme, et al. who reported non-significant changes in liver enzyme activities upon administration of Cnidoscolus aconitifolius ethanol leaf extract. This indicates that the aqueous plant leaf extract may be hepatotoxic in nature in dose dependent manner. This could however be as a result of the presence of some toxic substances in raw Cnidoscolus aconitifolius leaf. Emelike and Unegbu, [24] had earlier reported that toxic substances may be present in aqueous leaf extract of Cnidoscolus aconitifolius leaf. This calls for further characterization of this plant in order to fully identify the toxic substances that may have induced the toxicity. Findings from the present study shows that at increased dosage, aqueous leaf extract of Cnidoscolus aconitifolius may induce hepatocellular damage.

Total protein level from the present study was observed to decrease significantly in the groups treated with aqueous leaf extract of Cnidoscolus aconitifolius compared to control and the groups treated with ethanol leaf extract $(\mathrm{P}<0.05)$. This decrease in total protein in dose dependent ratio might be due to reduction in the functionality of the hepatocytes which in turn may have resulted in decrease in hepatic capacity to synthesize protein. Shukla and Bhatia [44] noted that decrease in total protein is often associated with increase in hepatic cell injury. Findings from this study also showed slight increase though not significant $(\mathrm{P}<0.05)$ in the total protein level of groups treated with ethanol leaf extracts. This also confirms further the non-hepatotoxic potentials of ethanol leaf extract of Cnidoscolus aconitifolius and suggest that ethanol extract may have hepatoprotective capacity in cases of liver injury.
The albumin level recorded from the present study shows significant decrease in the groups treated with 400,600 and $800 \mathrm{mg} / \mathrm{kg}$ body weight of aqueous leaf extract. This may also be attributed to the hepatocellular damage caused by aqueous leaf extract of Cnidoscolus aconitifolius. Saba, et al. [45] posited that significant decrease in serum albumin level is associated with active cirrhosis and biliary liver damage. Results also showed non-significant increase in albumin level of rats treated with ethanol leaf extract of Cnidoscolus aconitifolius. This further suggest that ethanol leaf extract of this plant may not precipitate liver damage but rather may be effective in management of liver related diseases.

\section{Conclusion}

From this study, Cnidoscolus aconitifolius ethanol leaf extract administration at doses of $200,400,600$ and $800 \mathrm{mg} / \mathrm{kg}$ body weight may be safe while aqueous leaf extract at 400,600 and $800 \mathrm{mg} / \mathrm{kg}$ body weight showed evidence of cumulative toxicity and degenerative liver tissues as reflected by the significant changes in the serum liver function indices studied. It is evident from this study that intake of aqueous leaf extract of Cnidoscolus aconitifolius should be regulated and therefore suggests that leaves of this plant should be detoxified before consumption in order to expunge some of the toxic substances that may be contained in the raw plant leaves.

\section{References}

1. Dhanalakshmi R, Manavalan R (2014) Bioactive compounds in leaves of Corchorus trilocularis L by GC-MS Analysis. Int J Pharmtech Res 6: 1991-1998.

2. Sowmya S, Gopalakrishnan VK, Poornima K (2015) Enzymatic and nonenzymatic antioxidant activity of tabernaemontana divaricate R.Br. against DEN and Fe-NTA induced renal damage in wistar albino rats. J Appl Pharm Sci 5: 33-37.

3. Ebeye OA, Ekundina VO, Ekele CM, Eboh DEO (2015) The histological effect of Cnidoscolus aconitifolius aqueous leaf extracts on the archetecture of the ovary, testis and sperm cells of adult wistar rats. Intr J Herbs and Pharmcol Res 4: 7-17.

4. Oluwatosin AA, Adekunbi A, Ademola AO (2011) Cnidoscolus aconitifolius leaf extract protects against hepatic damage induced by chronic ethanol administration in wistar rats. Alcohol 46: 445-451.

5. Oyeyemi MO and Ajani OS (2014) Haematological parameters and serum testosterone of west African dwarf rams treated with aqueous extract of Cnidoscolus aconitifolius (Chaya). J Med Plants Res 8: 571-575.

6. Fagbohun ED, Egbebi, AO, Lawal OU (2012) Phytochemical screening, proximate analysis and in-vitro antimicrobial activities of methanolic extract of Cnidoscolus aconitifolius leaves. Intr J Pharma Sci Rev Res 13: 28-33.

7. Iwalewa EO, Adewunmi CO, Omisore NO, Adebanji OA, Azike CK, et al. (2005) Pro and antioxidant effects and cytoprotective potentials of nine edible vegetables in southwest Nigeria. J Med Food 8: 539-544.

8. Yakubu MT, Akanji MA, Oladiji AT, Olatinwo AO, Adesokan AA (2008) Effect of Cnidoscolus aconitifolius leaf extract on reproductive hormones of female rats. Iran J Reprod Med 6: 149-155.

9. James CS (1995) Analytical chemistry of foods. Blakie academic and professional, London. pp. 505-509.

10. Chang SKC (2003) Protein analysis.3rd edition, New York: Kluwer academic/plenum publisher. pp. 7-10.

11. Muller HG, Tobin G (1980) Nutrition and food processing. London: Croom Helm London. pp. 24-32

12. Kirk R, Sawyer R (1998) Pearson's composition and analysis of foods. 9th edn Addison Wesley Longman Ltd, England

13. AOAC Official Methods of Analysis (1975) Association of official analytical chemistry 7 th edn, Washington DC. 
14. Barakat MZ, Shehab SK, Darnish N, Zahermy EI (1975) Determination of ascorbic acid from plants. Analyst Biochemistry 153: 225-245.

15. Gidado A, Ameh DA, Atawodi SE (2005) Effect of Nauclea latifolia leaves aqueous extracts on blood glucose levels of normal and alloxan- induced diabetic rats. Afr J Biotechnol 4: 91-93.

16. Baker FF, Silventon RE (1976) Introductory to medical laboratory technology 5th edn, Butterworth and Co. Publishers LTD Loncbn pp. 564-604.

17. Cheesbrough M (2004) District laboratory practice in tropical countries. Cambridge University Press UK pp. 299-327.

18. Reitman S, Franklin S (1957) A colorimetric method for the determination of serum glutamine oxalo-acetic and glutamic pyruvic transaminases. Am J Clin Pathol 28: 56-58.

19. Bassey OA, Lowery OH, Brook M (1946) One port colorimetric method of determining alkaline phosphatase in serum or plasma. J Bud Chem 164: 321 .

20. Henry RS, Winkelman A (1974) Clinical chemistry principles and techniques. $2^{\text {nd }}$ edn. Herper and Row Hagerstown.

21. Douman BT, Watson WA, Biggs AG (1971) Albumin standards and measurement of serum albumin with bromocresol green. Clin Chem Acta 1: 146-147.

22. Iwuji SC, Nwafor A, Egwurugwu J, Ejeta K, Akpan U, et al. (2013) Comparative characterization of the phytomedicinal constituents of Cnidoscolus aconitiflius leaf extracts. Am j PharmTech res 3: 780-784.

23. Ganiyu $\mathrm{OBOH}$ (2005) Effect of some post-harvest treatments on the nutritional properties of Cnidoscolus aconitifolius leaf. Pakistan J Nutr 4 226-230.

24. Emelike CU, Unegbu GO (2015) Effects of oral administration of Cnidoscolus aconitifolius leaf extract (Chaya Tea) on biomarkers of cardiovascular system of Wistar albino Rats. Adv Biol Res 9: 182-188.

25. Yussuf AA, Mofio BM, Ahmed AB (2007) Proximate and mineral composition of Tamarindus indica Linn. 1763 seeds. World J Sci 2: 1-4.

26. Umar KJ, Hassan LG, Dangoggo SM, Ladan MJ (2007) Nutritional composition of water spinach (Ipomea aquatica Forsk) leaves. J Appl Sci 7: 803-809.

27. Bibi S, Dastagir G, Hussain F, Sanaullah P (2006) Elemental composition of Viola odorata Linn. Pakistan J Nutr 12: 141-143.

28. Okereke EA, Ayalogu AO, Akaninwor JO (2006) Effect of diets contaminated with crude petroleum product (Bonny light and Facados) on the haematological parameters of wister albino rats. JNES 3: 160-166.

29. Otitoju GTO, Ene-Obong HN, Otitoju O (2014) Macro and micro nutrient composition of some indigenous green leafy vegetables in SouthEast Zone Nigeria. J Food Process Technol 5: 389-343.

30. Bahadur A, Chaudhry Z, Jan G, Danish M, Rehman A, et al. (2011) Nutritional and elemental analyses of some selected fodder species used in traditional medicine. Afr J Pharm Pharmacol 5: 1157-1161.
31. Ishida H, Suzuno H, Sugiyama N, Innami S, Todokoro T(2000) National evaluation of chemical component of leaves stalks and stem of sweet potatoes. Food Chem 68: 359-367.

32. Adeyeye E, Otokili MKO (1999) Proximate composition and some nutritionally valuable minerals of two varieties of Capsicum annum. Discov Innov 11: 75-81.

33. Aberoumand A, Deokule SS (2009) Studies on nutritional values of some wild edible plants from Iran and India. Pakistan J Nutr 8: 26-31.

34. Ramula P, Rao PU (2003) Dietary fibre content of fruits and leafy vegetables. Nutr News 24: 1-6.

35. Emebu PK, Anyika JU (2011) Proximate and mineral composition of Kale (Brassica oleracea) grown in Delta State, Nigeria. Pakistan J Nutr 10: 190-194.

36. Lukaski $\mathrm{CH}$ (2004) Vitamin and mineral status: Effect on Physical performance. Nutrition Research Centre 20: 632-644.

37. Chinyere GC, Ikpoh JC, Osuocha KU (2015) Serum lipid profile and liver enzymes of rats fed Lageneria sphaerica (wild bottle gourd) supplemented diet. Intr Res J Biochem Biotech 2: 28-36.

38. Aye PA (2013) Nutrient digestibility and haematological indices of west African dwarf goats fed Cnidosculus aconitifolius multinutrient blocks as supplement. Agri Bio J North America 4: 375-383.

39. Mord JC (2012) Anti-diabetic potential of the aqueous leaf extract of Cnidoscolus aconitifolius on Streptozotocin (STZ) induced diabetes in Wistar rat hepatocytes. Curr Res J Bio Sci 4: 164-167.

40. Odokuma E I (2012) Histological effects of alcoholic extract of Cnidoscolus aconitifolius on bone marrow biopsy in adult male Wistar Rats. Basic Sci Med 1: 6-8.

41. Adebayo AH, Tan NH, Akindahunsi AA, Zeng GZ, Zang YM (2010) Anti-cancer and antiradical scavenging activity of Ageratum conyzoides L (Astereceae). Pharmacogn Mag 6: 62-66.

42. Rej R (1997) Aspartate aminotransferase activity and iso-enzymes proportions in human liver tissue. Clin Chem 24: 1971-1978.

43. Majekodunmi SO, Ademola AO, Oluwatoya AO (2014) Ameliorative effects of the ethanolic seed extract of Mucuna pruiens in alloxan induced biochemical alteration in male wistar rats. Phamacologi 5: 177-183.

44. Shukla A, Bhatia SJ (2010) Outcome of patients with primary hepatic venous obstruction treated with prime anticoagulant alone. Indian J Gastroenterol 29: 8-11

45. Saba AB, Oyagbemi AA, Azeez OI (2010) Amelioration of carbon tetrachloride-induced hepatotoxicity and haemotoxicity by aqueous leaf extract of Cnidoscolus aconitifolius leaf in rats. Niger J Physiol Sci 25: $139-147$ 